anales de psicología, 2017, vol. $33, \mathrm{n}^{\circ} 3$ (october), 433-435 http://dx.doi.org/10.6018/analesps.33.3.270921
C) Copyright 2017: Servicio de Publicaciones de la Universidad de Murcia. Murcia (Spain) ISSN print edition: 0212-9728. ISSN web edition (http://revistas.um.es/analesps): 1695-2294

\title{
Introduction to Monograph on Observational Data Analysis
}

\author{
M. Teresa Anguera
}

Universidad de Barcelona (Spain).

\begin{abstract}
Título: Introducción al número monográfico sobre Análisis de datos observacionales.

Resumen: En la breve Introducción se muestra el agradecimiento a Anales de Psicologia por la publicación del número monográfico. La satisfacción por la publicación de este número monográfico se centra en diferentes motivos, como el avance cuantitativo y cualitativo de la producción científica sobre la metodología observacional que se ha producido en el último cuarto de siglo, superándose la respuesta a críticas continuadas que han recibido por considerarse meramente estudios descriptivos, el interés creciente en el estudio de la cotidianeidad desde muchas facetas diversificadas, y por los avances metodológicos realizados en los últimos años. Como consecuencia de estos avances, la producción científica ha ido alcanzando cotas satisfactorias en la publicación y difusión de trabajos realizados.

Asimismo, se comenta brevemente cada uno de los trabajos que conforman este número monográfico.

Palabras clave: Metodología observacional; cotidianeidad; mixed methods; complementariedad de datos; diversificación metodológica.
\end{abstract}

I would like to sincerely thank Anales de Psicologia for publishing this monograph "Observational Data Analysis". This publication is important for several reasons.

First, there were several decades in the last century in which observational studies received little attention from national and international scientific communities and were attributed a mere anecdotal, marginal status.

Second, there has been a steady increase in scientific publications on observational methodology over the last 25 years that has helped to consolidate the position of this methodology as a scientific method per se. In 1990, Arnau, Anguera, and Gómez published a book that laid the foundation for distinguishing between different types of studies based on the concept of internal control, i.e., the degree to which a study method influences the participants being studied. They established a spectrum embracing situations ranging from spontaneous behavior in everyday settings to laboratory experiments in which all possible sources of variance need to be controlled. Observational methodology was clearly positioned at the end of the spectrum featuring studies of spontaneous behavior in natural settings.

Third, scientific communities with an interest in methodology have taken an increasingly sympathetic stance towards observational data, which, within a more classic understanding of the scientific method, were traditionally viewed as merely descriptive and incapable of providing novel insights or "discoveries". This is no longer the case.

Fourth, there has been growing interest in studying everyday behavior (Bolger, Davis, \& Rafaeli, 2003; Mehl \& Conner, 2012; Portell, Anguera, Hernández-Mendo, \& Jons-

* Correspondence address [Dirección para correspondencia]: M. Teresa Anguera. Facultad de Psicología. Universidad de Barcelona. Campus Mundet. Po Vall d'Hebron, 171. 08035 Barcelona (Spain). E-mail: tanguera@,ub.edu
Abstract: In our introduction, we express our gratitude to Anales de Psicologia for publishing this monograph, which embodies many of the achievements that have been made in observational data analysis over the past quarter of a century. Scientific production in the area of observational methodology has improved both quantitatively and qualitatively over this period, helping to overcome the negative perceptions perpetuated by critics who viewed it as a merely descriptive methodology. Another source of satisfaction is the growing interest in the study of everyday behavior from multiple angles and perspectives, and the methodological advances that have paved the way for even further developments. Thanks to this progress, the publication and dissemination of research grounded in observational methodology has reached satisfactory levels.

The introduction concludes with a brief description of the articles included in the monograph.

Keywords: Observational methodology; daily life; mixed methods; complementarity of data; methodological diversification.

son, 2015; Takala, Pehkonen, Forsman, Hansson, Mathiassen, Neuman et al., 2010) supported by the increasing recognition that studies of spontaneous behavior enable an extraordinarily "rich" analysis embracing many facets of everyday life and produce data that can be integrated with other types of data such as physiological measurements and questionnaire responses. This possibility of merging qualitative and quantitative findings is not something that was expected of observational studies if we consider more traditional views of scientific inquiry (Ato, López, \& Benavente, 2013).

Fifth, enormous methodological advances have been made in recent years. There have been calls for observational methodology to be considered a mixed method per se (Anguera \& Hernández-Mendo, 2016), clarifications on the distinction between direct and indirect observation (competitive research, development and innovation project $\mathrm{I}+\mathrm{D}+\mathrm{I}$ DEP2015-66069-P, 2015-2017), and, of course, advances in software programs that have greatly facilitated analyses (Hernández-Mendo, Castellano, Camerino, Jonsson, BlancoVillaseñor, Lopes, \& Anguera, 2014). All these advances have been warmly welcomed and embraced, as demonstrated by the notable increase in observational methodology studies published in top-ranking journals. The prestigious journal Frontiers in Psychology, for instance, recently published a Research Topic called "Systematic observation: Engaging researchers in the study of daily life as it is lived".

For all these reasons, I am grateful to Anales de Psicología for producing this monograph, which we have called "Observational Data Analysis". Studies analyzing data collected by observational methodology are growing and the techniques available are becoming increasingly systematized (Anguera \& Hernández-Mendo, 2015; Blanco-Villaseñor, Losada, \& Anguera, 2003), with new approaches appearing constantly. 
In the rest of this introduction, I will briefly comment on the main contributions of the articles in this monograph to the analysis of observational data:

The study by Jesús Ortigosa, Rafael Reigal, Mariona Portell, Verónica Morales-Sánchez, and Antonio HernándezMendo, entitled Automated observation: heart rate variability and its relationship with performance-related psychological variables in young swimmers, shows how electronic devices can be used for the systematic observation of heart rate variability in an approach that has been hailed as a rapid and efficient means for evaluating stress responses in certain situations. The authors studied the relationship between heart rate variability and different psychological variables (sleep quality, mood, and self-esteem) in young swimmers and investigated how these were linked to performance.

The article by Marta Castañer, Sílvia Puigarnau, Raúl Benítez, Valentino Zurloni, and Oleguer Camerino, How to merge observational and physiological data? A case study of motor skills patterns and heart rate in exercise programs for adult women, addresses the challenge of combining categorical observational data and continuous physiological data in a study of adult women designed to show how workout sessions equipped with a greater range of motor and cognitive tasks resulted in greater individual heart rate variability and greater synchrony between participants. They applied Hidden Markov Models to analyze heart rate data and categorical motor performance data recorded using the OSMOS-in context observation instrument (Castañer, Torrents, Anguera, Dinušová, \& Jonsson, 2009). These models have proven to be an effective means of integrating different types of data in other fields.

The article by Angel Blanco-Villaseñor and Elena Escolano-Pérez, Observational data analysis using generalizability theory and general and mixed linear models: an empirical study of infant development, addresses the challenges of measuring the development of logic and executive functions in infants. The successful acquisition of these competencies in early childhood is crucial for optimal development in subsequent years. Using generalizability theory and concepts of analysis of variance, they undertook a triple analysis of reliability, validity, and sample size estimation and also showed the potential applications of individual growth curves based on repeated measures within the framework of general and mixed linear models.

The study by Rubén Maneiro, José Luis Losada, Claudio A. Casal, and Antonio Ardá, entitled Multivariate analysis of indirect free kicks in the FIFA World Cup 2014, analyzed 506 indirect free kicks taken in 64 matches at the 2014 FIFA World Cup in Brazil. Using univariate, bivariate (chi-square and other association measures), and multivariate (binary logistic regression) analyses, they identified significant predictors of successful free kicks, and showed that these set-plays have a potentially important impact on the final outcome of matches.

The study by Rafael Tarragó, Xavier Iglesias, Daniel Lapresa, M. Teresa Anguera, Laura Ruiz-Sanchís, and Javier
Arana, called Analysis of diachronic relationshits in successful and unsuccessful behaviors by world fencing champions using three complementary techniques, used T-pattern analysis, lag sequential analysis, and polar coordinate analysis to investigate successful and unsuccessful tactics and strategies by world fencing champions using data collected with the ESGRIMOBS observation instrument (Tarragó, Iglesias, Michavila, Chaverri, Ruiz-Sanchís, \& Anguera, 2015). This combined use of techniques frequently used in observational methodology was found to be very positive.

The study by Julen Castellano, Eneko Fernández, Ibon Echeazarra, Daniel Barreira, and Julio Garganta, entitled Influence of pitch length on inter-and intra-team behaviors in youth soccer, investigated how the collective behavior of U-13 and U14 soccer players changed in response to modifications to pitch length in small-sided games. They analyzed and compared numerous indicators of group behavior (width and length of teams, effective area of play, distance between centroids, and stretch indexes) in the two groups using four game formats in which the only variable modified was length. They observed significant differences in means and SDs and analyzed their impact based on effect size. Finally, they applied entropy measures to evaluate the predictability of behavior in the different game formats used.

The article by Carlos Santoyo, Gudberg K. Jonsson, M. Teresa Anguera, and José Antonio López-López, Observational analysis of the organization of on-task behavior in the classroom using complementary data analysis, addressed a subject that has raised concerns among international bodies: time management in classrooms. They performed an observational study using the SOC-IS observation instrument (Santoyo, Espinosa, \& Bachá, 1994) and analyzed the data using four techniques: T-pattern analysis, lag sequential analysis, trend analysis (linear regression), and polar coordinate analysis. The progressive interpretation of results seen through the lens of the four techniques provided an interesting depth of analysis, with converging and diverging insights.

Finally, João Prudente, Duarte Sousa, Pedro Sequeira, José Antonio López-López, and Antonio HernándezMendo, in a study called Analyzing the influence of playing time and partial score on the tactical behavior in the attack in handball, using the polar coordinates technique, assessed the complexities of offensive tactics in the European Men's Handball Championship by identifying behavioral patterns and investigating their association with stage of play and score. They used polar coordinate analysis to produce a vector map showing the complex network of prospective and retrospective relationships between behaviors.

We sincerely hope that the studies in this monograph will illustrate the numerous possibilities offered by observational methodology in a broad range of areas, demonstrate both its rigor and flexibility, and show that it is the only truly valid option for studying spontaneous behavior in natural settings. 


\section{References}

Anguera, M. T., \& Hernández-Mendo, A. (2015). Técnicas de análisis en estudios observacionales en ciencias del deporte [Data analysis techniques in observational studies in sport sciences]. Cuadernos de Psicología del Deporte, 15(1), 13-30.

Anguera, M. T., \& Hernández-Mendo, A. (2016). Avances en estudios observacionales en Ciencias del Deporte desde los mixed methods [Advances in mixed methods observational studies in sports sciences]. Cuadernos de Psicología del Deporte, 16(1), 17-30.

Arnau, J., Anguera, M. T., \& Gómez, J. (1990). Metodología de la investigación en Ciencias del Comportamiento [Research Methodology in Behavioral Sciences]. Murcia: Secretariado de Publicaciones de la Universidad de Murcia.

Ato, M., López, J. J., \& Benavente, A. (2013). Un sistema de clasificación de los diseños de investigación en psicología [A classification system for research designs in psychology]. Anales de Psicología, 29(3), 1038-1059.

Blanco-Villaseñor, A., Losada, J. L. \& Anguera, M. T. (2003). Analytic techniques in observational designs in environment-behavior relation. Medio Ambiente y Comportamiento Humano, 4(2), 111-126.

Bolger, N., Davis, A., \& Rafaeli, E. (2003). Diary methods: capturing life as it is lived. Annual Review of Psychology, 54, 579-616.

Castañer, M., Torrents, C., Anguera, M. T., Dinušová, M., \& Jonsson, G. K. (2009). Identifying and analyzing motor skill responses in body movement and dance. Behavior Research Methods, 41, 857-867.

Hernández-Mendo, A., Castellano, J., Camerino, O., Jonsson, G. K., Blanco-Villaseñor, A., Lopes, A. \& Anguera, M. T. (2014). Programas informáticos de registro, control de calidad del dato, y análisis de datos [Observational software, data quality control and data analysis]. Revista de Psicología del Deporte, 23(1), 111-121.
Mehl, M. R., \& Conner, T. S. (2012). Handbook of Research Methods for Studying Daily Life. New York, N.Y.: The Guilford Press.

Portell, M., Anguera, M. T., Hernández-Mendo, A., \& Jonsson, G. K. (2015). Quantifying biopsychosocial aspects in everyday contexts: an integrative methodological approach from the behavioral sciences. Psychology Research and Behavior Management, 8, 153-160.

Proyecto competitivo I+D+i (2015-2017). La actividad física y el deporte como potenciadores de estilo de vida saludable: Evaluación del comportamiento deportivo desde metodologias no intrusivas [The role of physical activity and sport in the promotion of healthy lifestyle habits: The evaluation of sport behavior using non-intrusive methods and advanced technology]. DEP2015-66069-P (Coordinated by M.T. Anguera).

Santoyo, C. Espinosa, M. C. \& Bachá, M. G. (1994). Extensión del sistema de observación conductual de las interacciones sociales: calidad, dirección, contenido contexto y resolución [Extension of the behavioral observation system for social interaction: quality, direction, content, context, and resolution]. Revista Mexicana de Psicología, 11, 55-68.

Takala, E. P., Pehkonen, I., Forsman, M., Hansson, G - A., Mathiassen, S. E., Neuman, W. P., SjØgaard, G., Veiersted, K. B., Westgaard, R.H., \& Winkel, J. (2010). Systematic evaluation of observational methods assessing biomechanical exposures at work. Scandinavian Journal of Work, Environment \& Health, 36(1), 3-24.

Tarragó, R., Iglesias, X., Michavila, J.J., Chaverri, D., Ruiz-Sanchís, L., \& Anguera, M. T. (2015). Análisis de patrones en combates de espada de alto nivel [Analysis of patterns in bouts elite epee]. Cuadernos de Psicología del Deporte, 15(1), 149-158.

(Article received: 12-10-2016; revised: 12-12-2016; accepted: 26-12-2016) 